\title{
Investigating the Role of Self-Efficacy in Manipulating Instructional Textbooks: A Matter of Iranian Language Teachers
}

\author{
Mahyar Ganjabi (Corresponding author) \\ Department of Foreign Languages, Payame Noor University, P.O. Box: 19395-4697, Tehran, Iran \\ E-mail: mahyarganjaby@gmail.com \\ Manoochehr Jafarigohar \\ Department of Foreign Languages, Payame Noor University, P.O. Box: 19395-4697, Tehran, Iran \\ E-mail: jafarigohar2007@yahoo.com \\ Hassan Soleimani \\ Department of Foreign Languages, Payame Noor University, P.O. Box: 19395-4697, Tehran, Iran \\ E-mail: arshia.soleimani@gmail.com \\ Hassan Iravani \\ Department of Foreign Languages, Payame Noor University, P.O. Box: 19395-4697, Tehran, Iran \\ E-mail: iravani_tefl@yahoo.com
}

Received: 05-07-2013

Accepted: 10-08-2013

Published: 01-11-2013

doi:10.7575/aiac.ijalel.v.2n.6p.76

URL: http://dx.doi.org/10.7575/aiac.ijalel.v.2n.6p.76

\begin{abstract}
Guided by the research on the self-efficacy beliefs on the one hand and the works done on instructional materials evaluation and selection on the other, this study followed a two-fold purpose: first, examining teachers' reactions towards prescribed textbooks and second, investigating relationships between such reactions and teachers' sense of selfefficacy. Accordingly, 312 Iranian in-service high school English language teachers $(\mathrm{N}=312)$ were asked to respond to two scales: Self-Efficacy to Influence Instructional Textbooks (SEIIT) scale devised by the researchers according to the principles of Social Cognitive Theory and the 12-item Teacher's Sense of Efficacy Scale (TSES) developed by Tschannen-Moran and Woolfolk Hoy (2001). The data analysis revealed acceptable psychometric properties of the newly developed scale and a degree of correlation between self-efficacy in teaching and in dealing with prescribed textbooks. The findings also provided a number of practical and theoretical implications.
\end{abstract}

Keywords: Social cognitive theory; self-efficacy; human agency; prescribed instructional textbooks

\section{Introduction}

The English language, as a contemporary lingua franca, is becoming so favorable across the world that providing learners with suitable textbooks has turned the respective publication market into a multi-million dollar industry (Sheldon, 1988). Every now and then, a new English textbook emerges claiming to be the best book ever. The ongoing efforts to publish a book that best suits the needs of EFL learners is mainly due to the fact that textbooks "represent the visible heart of any ELT program" (Sheldon, 1988, p.237). Hence, the first principal element assessed in a language program is the type of textbook used during a course. In other words, as Hutchinson and Torres (1994) suggest, the textbook is a common element of every language teaching program: "millions of copies are sold every year, and numerous aid projects have been set up to produce them in [various] countries....No teaching-learning situation, it seems, is complete until it has its relevant textbook" (p. 315).

In a situation where we are witnessing the upsurge of efforts to publish the most suitable book ever written, teachers as those who in addition to students have another constant in their lives named textbooks are experiencing two circumstances. First, there are those teachers free to choose whatever textbooks seem to be appropriate to their teaching context and to their students' linguistic needs. On the other hand, there are a group of teachers deprived of such an opportunity who are, instead, required to teach from the textbooks prescribed by their educational authorities (Byrd, 2001; Razmjoo, 2007). The latter group seems to be servant and not master of such instructional textbooks (Cunningsworth, 1984; Garinger, 2002).

Taking this into account, and given the fact that there are a lot of teachers across the world who are working in centralized top-down educational systems, and gripping with impoverished prescribed instructional textbooks from which they are required to teach, this study was designed to investigate the role of self-efficacy in such contexts in which teachers are confronted with textbooks that might not address students' language needs. To put it another way, this study sought to examine the degree to which teachers perceive themselves capable (i.e. efficacious) of making necessary modifications to the prescribed textbooks, hence rendering more realistic and suitable textbooks. Using a 
newly-developed questionnaire based on the context of research and inspired by the guidelines presented by selfefficacy scholars (such as Bandura, 2001, 2006b) and criteria proposed for textbook evaluation and selection (such as Byrd, 2001), the researchers probed underlying teachers' perceptions either as slaves of prescribed textbooks or as individuals with power to modify textbooks so as to adapt them to the needs of English language learners.

\section{Theoretical Framework}

\subsection{Self-efficacy Conceptualization and Measurement}

The early traces of self-efficacy originated from social learning theory (Rotter, 1954) that was founded on behaviorism one basic principle of which is the stimulus-response principle, meaning every human action is a response to an environmental stimulus (Howell, 2005). Social learning theory, benefiting from the scientific power of this theory, tends to analyze not only aspects of human behavior but also internal thoughts processes often overlooked by behaviorists (Pajares \& Schunk, 2002). Accordingly, Rotter (1954) contends that environment and behavior have to be involved in studying personality; moreover, the individual's internal thoughts should be taken into account in understanding the workings of motivation and its relation to failure and success.

However, these premises advocated by social learning theory adherents have been dismissed mainly for two reasons: first, their excess determinism in accounting for human behavior and second, their negligence of the role human cognition plays in behavior (Bandura, 1989). Attempting to put forward an alternative theory free from such shortcomings, in 1977, Albert Bandura in his often-cited article, "Self-efficacy: Toward a Unifying Theory of Behavioral Change", and later in 1986 in his book, "Social Foundations of Thought and Action: A Social Cognitive Theory", proposed social cognitive theory and explained that "perceptions self-mediate human behavior, that is, individuals give meaning and weight to events in their environment through the filter of their beliefs about themselves" (Soodak \& Podell, 1998, p. 78). Thus, individuals favor those activities and situations in which they feel competent and avoid situations in which they believe they cannot demonstrate their capabilities (Bandura, 1993, 1997; Pajares, 1992 , 1996; Tournaki \& Podell, 2005).

Reconceptualizing self-efficacy as one of the major theoretical constructs of social cognitive theory, Bandura defines it as "the conviction that one can successfully execute the behavior required to produce the outcomes" (1977, p. 193) or more recently as "beliefs in one's capabilities to organize and execute the courses of action required to produce given attainments" (1997, p. 3). He also notes that self-efficacy has a futuristic orientation, meaning self-efficacy beliefs are related with perceptions of competence rather than actual level of competence (1997).

With new research, questions are raised regarding how best to measure teacher's sense of self-efficacy (TschannenMoran \& Woolfolk Hoy, 2001; Tschannen- Moran, Woolfolk Hoy, \& Hoy, 1998; Yough, 2008). Such concerns have resulted in the development of a number of self-efficacy scales based on two theoretical traditions, namely social learning (e.g. 'attributional' and 'locus of control' theories) and social cognitive theories (Ross, 1994). Among the early measures of teaching self-efficacy is Rand Measure developed by Rand Corporation. It is composed of two items and claimed to measure teachers' locus of control orientation with regard to teaching (Tschannen-Moran \& Woolfolk Hoy, 2001). Using Rotter's (1954) locus of control theory, Rand researchers attempted to determine whether teachers saw the outcome of their performance to be within/out of their grip (Armor, Conroy-Osegnera, Cox, \& King, 1976). As pioneer researchers working on teachers' sense of self-efficacy, they define teaching self-efficacy as "the extent to which teachers believed that they can control the reinforcement of their actions, that is, whether the control of reinforcement lay within themselves or in the environment" (Tschannen-Moran \& Woolfolk Hoy, 2001, p.784). Although interesting results came out of this two-item scale and it paved the way for further research on self-efficacy construct, there were a number of researchers concerned about the reliability of the scale and attempted to develop more comprehensive measures.

In the early 1980s, other researchers employed attribution theory as a framework to conceptualize teaching selfefficacy, as teachers' belief about their capacity to affect student learning (Guskey, 1987, 1988). Inspired by Weiner's (1979) conceptualization of attribution theory, Guskey (1981) developed his 30-item 100-point scale entitled Responsibility for Student Achievement (RSA). While RSA scale was being developed, other researchers were attempting first to boost the reliability of Rand Scale by increasing its number of questions and second to maintain a narrow conceptualization of the construct (Tschannen-Moran \& Woolfolk Hoy, 2001). The outcome of these endeavors was a 7-item measure called the Webb self-efficacy scale (Ashton \& Webb, 1986). Upon applying their scale, Webb and his colleagues found that teachers who reported higher levels of teaching self-efficacy were more patient in their teaching interactions. Although RSA scale was more comprehensive than the Rand Measure, it was not welcomed and adopted by other researchers in the field (Tschannen-Moran \& Woolfolk Hoy, 2001).

As stated before, however, not all scales were based on social learning theory. Rather, a significant number of them were developed using Bandura's social cognitive theory as their underlying foundation. Gibson and Dembo's (1984) scale is just one of them. They were not satisfied with the validity and reliability of the Rand two-item scale and sought to develop and measure teaching self-efficacy based on Bandura's conceptions. The outcome of this dissatisfaction was the development of the Teacher Efficacy Scale (TES), composed of a 30-item 6-point Likert scale ranging from strongly disagree to strongly agree. To come up with the factorial composition of the scale, they ran principal component factor analysis and found two factors: Personal Teaching Efficacy (PTE), corresponding to Bandura's selfefficacy, and teacher's sense of General Teaching Efficacy (GTE), corresponding to Bandura's outcome expectancy (Tschannen-Moran \& Woolfolk Hoy, 2001). Although this measure of teaching self-efficacy gained popularity among 
self-efficacy scholars, there were still conceptual and statistical problems such as "clarity about the meaning of the two factors and the instability of the factor" (Tschannen-Moran \& Woolfolk Hoy, 2001, p. 789).

Another scale founded on the social cognitive theory is a 19-item scale called Teachers' Sense of Efficacy Scale (TSES), developed by Tschannen-Moran and Woolfolk Hoy (2001). To develop this scale, these scholars examined the various scales developed before then such as Gibson and Dembo's (1984) Likert-type scale and Bandura's (2001) scale, and decided to develop a scale with an expanded list of teacher capabilities based on Bandura's (2001). This scale includes such teaching tasks as assessment, adjusting the lesson to individual student needs, dealing with learning difficulties, repairing student misconceptions, and motivating student engagement and interest (Tschannen-Moran \& Woolfolk Hoy, 2001).

Bandura (2001) himself also developed a measure of teacher's self-efficacy. He emphasizes that teachers' sense of selfefficacy varies across different types of tasks or across different subject matters that teachers are asked to perform or to teach (Hoy \& Spero, 2005). This measure attempts to build a universal picture of teachers' sense of self-efficacy without becoming too narrow or too specific. This 30-item 9-point scale instrument is composed of seven subscales: Efficacy to influence decision making; efficacy to influence school resources; instructional efficacy; disciplinary efficacy; efficacy to enlist parental involvement; efficacy to enlist community involvement; and efficacy to create a positive school climate (Tschannen-Moran, Woolfolk Hoy \& Hoy, 1998). However, few research studies have employed this scale (Hoy \& Spero, 2005).

\section{Devising a New Measure of Self-Efficacy}

There are a plethora of research studies investigating relationship between self-efficacy and such factors as student learning and achievement, and professional learning opportunities (Bruce, Esmonde, Ross, Dookie, Beatty, 2010), teacher practices and policies used in the classroom (Haverback \& Parault, 2011), innovative classroom techniques (Allinder, 1995; Gibson \& Dembo, 1984; Guskey, 1988; Skaalvik \& Skaalvik, 2007; Wolters \& Daugherty, 2007), teacher effort and productivity (Ashton \& Webb, 1986; Podell \& Soodak, 1993), satisfaction with profession and resilience to occupational retention (Ross 1998; Goddard, Hoy, \& Hoy 2000; Wheatley 2005), classroom management approaches (Woolfolk \& Hoy, 1990), students' own sense of self-efficacy (Anderson, Greene, \& Loewen, 1988), and views towards teaching and learning (Eren, 2009). However, to the best of researchers' knowledge there has been no documented attempt so far to investigate how teachers treat the prescribed textbooks they use, and whether they perceive themselves capable (i.e. efficacious) of modifying the textbooks in such a way that they become more compatible with students' learning needs. The development of Self-Efficacy to Influence Instructional Textbooks (SEIIT) Scale was driven by such a felt gap in the literature. To put it another way, the current research intended to investigate whether self-efficacy has any role in teachers' attempt to improve the textbooks' current quality rather than to check whether the teachers have positive or negative views towards high school English textbooks.

Reviewing the research studies done so far on self-efficacy shows that the only scale seems to partially tackle this problem is the one designed by Bandura (2001). As said above, Bandura's 30-item 9-point scale is composed of seven subscales only one of which seems suitable for this purpose (i.e. efficacy to influence school resources). However, this subscale has just one item: "How much can you do to get the instructional materials and equipment you need?". Common tells us that an answer to this single question cannot provide us with the whole story. In order to fill the gap, two factors underlying the theory of self-efficacy seem quite relevant. First, according to this theory, people's beliefs in their capabilities can have far-reaching effects on "the courses of action [they] choose to pursue, how much effort they put forth in given endeavors and how long they will preserve in the face of failures and obstacles..." (Bandura, 1997, p. 3). Therefore, it can be inferred that self-efficacy can have some influence on diverse aspects of human endeavor, only one aspect of which is language teaching. Second is the premise of human agency proposed in the self-efficacy theory (Bandura 1997). According to this premise, agency is a trait only possessed by humans, a main feature of which is intentional action and people's exercise of influence on what they do varies based on how much they believe in their personal self-efficacy, meaning "if people believe they have no power to produce results, they will not attempt to make things happen" (Bandura, 1997, p.3).

Therefore, self-efficacy beliefs from an agentic perspective (Bandura, 2006a) seem quite applicable in the face of those deeply-rooted problems that teachers confront in their routines of language teaching such as the type of textbooks from which they are required to teach. Hence, such beliefs are supposed to make teachers change or modify their route of actions in a way that will lead them to better outcomes. Additionally, every action done intentionally on the part of teachers to improve the status quo seems to be as an aspect of applying their agency. But the main question that now comes to mind is whether teachers with different levels of self-efficacy beliefs have different levels of agency and whether the exercise of agency is limited to those aspects of language teaching that are under complete control of language teachers - such as the teaching techniques employed in the classroom - or extend to other realms that are mainly fixed, and the teacher's only role is to modify, supplement, or improve such things as the instructional textbooks that are fixed and prescribed from the educational authorities. Hence, this scale was devised to examine the role of selfefficacy in influencing the instructional textbooks.

To write the scale's items, a number of interview sessions were scheduled with four in-service high school language teachers in order to determine the domains that should be tackled in the devised scale. Also, Bandura's (2006b) article, "Guide for Constructing Self-Efficacy Scales", was reviewed as a reliable source and also, the style of Bandura's (2001) scale was followed in the newly developed scale. According to Bandura (2006b), "the items should be phrased in terms of can do rather than will do. Can is a judgment of capability; will is a statement of intention" (p. 308). So to follow the 
principle of consistency and using Bandura's (2001) scale as a model, all the items began with "how much can you do". The consistent use of this phrase was supposed to not only free the respondents from comprehending the initial words of the items and hence making the task of respondents easier, but also to manifest the principle of agency, that is, it asked the respondents to show how much they can do to improve the textbooks' status quo rather than just criticizing the quality of the existing textbooks.

\section{The Present Study}

In Iran, government in general and Ministry of Education in particular are responsible for developing and implementing educational policies (Dahmardeh, 2009, 2011; Noora, 2008). These policies target different aspects of education such as school systems, curriculum standards, textbooks, etc. English textbooks are reading-based with aural and oral skills deemphasized (Eslami \& Fatahi, 2008; Ghorbani, 2009; Soori, Kafipour, \& Soury, 2011). That is, these skills are not part of final exams and students are not required to have a good command of them as a prerequisite for university entrance exams. Therefore, language teachers have to put more emphasis on reading, writing, grammar, and vocabulary and less or no emphasis on speaking, listening, and pronunciation (Eslami \& Fatahi, 2008). As a result, these textbooks do not prepare students for participating in real-life contexts in which aural and oral skills are more needed. Nowadays, however, language teachers are experiencing an ever increasing pressure from society, demanding them to practice oral and aural skills in the classroom, and to familiarize learners with the workings of these skills (Soori, Kafipour, \& Soury, 2011). Therefore, teachers are attempting to bridge the gap in language textbooks by including oral and aural tasks in class activities, despite not being a mandatory component of the curriculum.

To elucidate how teachers react to such institutional impediments as impaired prescribed textbooks and taking into account Bandura's (1997) words that "efficacious people perceive themselves to be capable of figuring out ways to circumvent or change institutional" and conversely "inefficacious people are less apt to exploit the enabling opportunities provided by the social system and are easily discouraged by institutional impediments" (p. 6), this study intended to: (a) investigate teaching self-efficacy of Iranian high school language teachers; (b) examine the psychometric properties and factor structure of SEIIT scale; and (c) inquire into the possible relationship between selfefficacy in teaching and in dealing with prescribed instructional textbooks.

\section{Method}

\subsection{Participants}

For the purpose of this study, convenience or opportunity sampling was employed to collect data from the participants. Therefore, a sample of 350 Iranian high school English language teachers were requested to take part in the study and to complete the scales, out of which 312 provided the necessary data for the study $(\mathrm{N}=312)$. These teachers were working in Tehran's public $(66.3 \%)$ and private $(33.7 \%)$ schools. Of the total sample, 192 were male $(61 \%)$ and $120(39 \%)$ were female. They aged from 35 to 55 years old, with teaching experience ranging from 3 to 25 years, and had academic degree ranging from BA to PhD in TEFL (See Table 1 for Further Information).

Table 1. The distribution of study participants by age, teaching experience and academic degree

\begin{tabular}{c|cccc|cccc|ccc}
\hline \multirow{3}{*}{ Participants } & \multicolumn{4}{|c|}{ Age (f) } & \multicolumn{4}{c|}{ TE by year (f) } & \multicolumn{3}{c}{ AD (f) } \\
\cline { 2 - 11 } & $\mathbf{2 0 - 3 0}$ & $\mathbf{3 0 - 4 0}$ & $\mathbf{4 0 - 5 0}$ & $\mathbf{5 0}$ & $\mathbf{5}$ & $\mathbf{5 - 1 0}$ & $\mathbf{1 0 - 1 5}$ & $\boldsymbol{7 1 5}$ & BA & MA & PhD \\
& 23 & 127 & 123 & 39 & 34 & 28 & 58 & 192 & 218 & 90 & 4 \\
\hline
\end{tabular}

\subsection{Measures}

Demographics questionnaire. The purpose of this questionnaire was to obtain the following information from the respondents: gender, teaching experience, and academic degree/s obtained. This questionnaire used a non-Likert response format and teachers were asked to provide the required information.

Teaching self-efficacy scale. To investigate high school English language teachers' sense of teaching self-efficacy, Teacher's Sense of Efficacy Scale (TSES) developed by Tschannen-Moran and Woolfolk Hoy (2001) was employed. There are two versions of TSES: a long one with 24 items and a short one with 12 items; however, due to time limitations the latter form was employed for the purpose of this study. It makes use of a 9-point scale ranging from nothing to a great deal and composed of three factors.

SEIIT scale. This scale was constructed according to the Bandura's characterization of self-efficacy in social cognitive theory and elicited information from Iranian high school English language teachers regarding their self-efficacy selfevaluation, with a view to enhancing the quality of the English textbooks they have available. It consisted of 15 items with a scale ranging from 1 (not at all) to 9 (a great deal; See Appendix A).

\subsection{Procedure}

The scales were translated into Persian in order to enhance participants' comprehension and to minimize answering time. Translation was done in two phases. First, they were translated into Persian by the researchers and then two professional translators were asked to check the accuracy of the translation. Second, two external professional translators who majored in Persian-to-English translation and had higher education degrees in TEFL were requested to translate the Persian back into English. This translation process from/to Persian aided the researchers in identifying any mistranslations. 
The newly-developed scale (i.e. SEIIT) included some compulsory activities. Accordingly, it went through two types of piloting: initial and final piloting. The initial piloting phase involved checking content and face validities. Four English language teachers who had higher education degrees in TEFL and were familiar with current trends in Applied Linguistics were invited to review the early version of the scale. As Dornyei (2003) notes, these teachers do not need to be specialists in the field, as they know the target population well. Therefore, they were asked to audit the items and answer them, and then to provide feedback.

At the second phase of piloting (i.e. final piloting), the reviewed and modified scale from the initial piloting phase went through actual experimentation. As recommended by Dornyei (2003), the final pilot group size needs not be very large and "the typical sample size at this stage is around $50( \pm 20)$ " (p. 66). Therefore, a sample size of 30 language teachers was recruited for this purpose. The study conducted some meaningful item analysis as the final step in the design of SEIIT scale. According to Dornyei (2003), the result of final piloting was used for checking two aspects of response pattern: a) looking for missing responses and possible signs of ambiguous instructions: for example, missing items showed that those particular items were suffering from such problems as difficulty and/or ambiguity, and b) modification or deletion of items receiving endorsement of almost everyone or almost no one.

The participants received a package of the three scales: Background Information Questionnaire, Teaching Efficacy scale, and SEIIT scale, which took approximately 20-25 minutes to complete. They could answer the scales either at school during break time, or at home.

\section{Results}

\subsection{Descriptive analysis}

Teaching self-efficacy scale. The pattern of responses to the items in this scale showed that Iranian high school English language teachers displayed a moderate level of teaching self-efficacy $(x=7.52, \mathrm{SD}=1.56)$. Also, descriptive statistics revealed that the participants perceived themselves to be better in classroom management $(\bar{x}=8.0, \mathrm{SD}=1.33)$ than in instructional strategies $(\tilde{x}=7.58, \mathrm{SD}=1.39)$ and student engagement $(\tilde{x}=7.01, \mathrm{SD}=1.89)$. Further analysis of response patterns indicated that the ability to: "Assist parents to help their children learn English" received the lowest rating from the high school English language teachers $(\bar{x}=5.71, \mathrm{SD}=2.24)$. Also, the sampled teachers rated highest the ability to: "Control disruptive behavior in your English class" $(\tilde{x}=8.22, \mathrm{SD}=1.33)$. High scores on the general teaching self-efficacy scale indicate a more robust belief of language teachers on their capabilities to teach language effectively. Descriptive statistics for the scale are presented in Table 2.

Table 2. Mean and standard deviation for teaching self-efficacy scale

\begin{tabular}{|c|c|c|c|}
\hline No. & Items & $\bar{x}$ & SD \\
\hline 1 & How well can you control disruptive behavior in your English class? & 8.22 & 1.33 \\
\hline 2 & How much can you do to motivate students who show low interest in learning English? & 7.10 & 1.52 \\
\hline 3 & How much can you do to get students to believe they can do well in English? & 7.49 & 1.55 \\
\hline 4 & How well can you help your students value learning English? & 7.48 & 1.47 \\
\hline 5 & To what extent can you craft good questions for eliciting responses from your students in English class? & 7.72 & 1.34 \\
\hline 6 & How well can you get students to follow classroom rules in your English class? & 8.01 & 1.26 \\
\hline 7 & How much can you do to calm a student who is disruptive or noisy in your English class? & 8 & 1.24 \\
\hline 8 & How well can you establish a classroom management system with your students in English class? & 8 & 1.21 \\
\hline 9 & How much can you use a variety of assessment strategies in your English class? & 7.80 & 1.32 \\
\hline 10 & $\begin{array}{l}\text { To what extent can you provide an alternative explanation or example in English class when students are } \\
\text { confused? }\end{array}$ & 8.04 & 1.40 \\
\hline 11 & How well can you assist parents to help their children learn English? & 5.71 & 2.24 \\
\hline 12 & How well can you implement alternative teaching strategies in your English class? & 7.37 & 1.56 \\
\hline
\end{tabular}

SEIIT scale. The general pattern of responses showed that the respondents had a moderate level of confidence in their ability to influence instructional textbooks, as shown by the descriptive statistics $(\tilde{x}=5.58, \mathrm{SD}=2.42)$. Analysis of responses given to items indicated that two items were rated highest by high school English language teachers: "To employ a variety of reading techniques to make your students better readers (based on the potentials of the current textbook)" $(\tilde{x}=6.79, \mathrm{SD}=1.88)$ and "To use the textbook to increase the grammaticality of your students' language (i.e. repeating the grammatical points presented in one lesson in other lessons so that to stabilize those points)" $(\bar{x}=6.56, \mathrm{SD}=1.76)$. However, item-specific means were lowest among the high school English language teachers for the ability: "To familiarize your students with the English culture using the available textbook?" $(\tilde{x}=4.32, \mathrm{SD}=2.52)$, "To meet individual language needs of your students using the available textbook" $(\bar{x}=4.84, \mathrm{SD}=2.32)$ and "To make the textbook's content relevant to real-life contexts (i.e. to be able to make a phone call or do shopping, etc.)" $(\dot{x}=4.91$, $\mathrm{SD}=2.58$ ). High scores on the SEIIT scale indicate a higher sense of self-efficacy for enhancing the quality of the prescribed textbooks in the way that learning outcomes are enhanced. Descriptive statistics and factor loadings for the scale are presented in Table 3. 
Table 3. Mean, standard deviation, and factor loadings for the SEIIT scale

\begin{tabular}{|c|c|c|c|c|}
\hline No. & Items & $x$ & SD & FL \\
\hline 1 & $\begin{array}{l}\text { How much can you do to make changes in the lessons to achieve better learning results (for example, changing } \\
\text { the sequence of different sections within the same lesson)? }\end{array}$ & 6.63 & 2.22 & .46 \\
\hline 2 & $\begin{array}{l}\text { How much can you do to supplement the materials presented in the textbook with other resources (short story, } \\
\text { newspaper, etc.)? }\end{array}$ & 6.37 & 2.28 & .49 \\
\hline 3 & $\begin{array}{l}\text { How much can you do to use the available textbook or additional resources to enhance the writing skill of your } \\
\text { students? }\end{array}$ & 6.13 & 2.19 & .54 \\
\hline 4 & How much can you do to make the textbook more interesting and attractive for your students at this age? & 6.64 & 2.08 & .63 \\
\hline 5 & $\begin{array}{l}\text { How much can you do to employ a diversity of tasks and exercises to teach the textbook in order to meet the } \\
\text { different learning styles and interests of your students? }\end{array}$ & 6.72 & 1.97 & .64 \\
\hline 6 & $\begin{array}{l}\text { How much can you do to employ a variety of reading techniques to make your students better readers (based on } \\
\text { the potentials of the current textbook)? }\end{array}$ & 6.79 & 1.88 & .62 \\
\hline 7 & $\begin{array}{l}\text { How much can you do to use the textbook to increase the grammaticality of your students' language (i.e. } \\
\text { repeating the grammatical points presented in one lesson in other lessons so that to stabilize those points)? }\end{array}$ & 6.56 & 1.76 & .45 \\
\hline 8 & How much can you do to improve your students' pronunciation using the textbook pronunciation exercises? & 6.11 & 2.41 & .48 \\
\hline 9 & $\begin{array}{l}\text { How much can you do to use the available textbook or additional resources to enhance the listening skill of your } \\
\text { students? }\end{array}$ & 5.13 & 2.55 & .59 \\
\hline 10 & $\begin{array}{l}\text { How much can you do to use the textbook to encourage students to use additional resources such as Internet for } \\
\text { further learning? }\end{array}$ & 5.08 & 2.65 & .56 \\
\hline 11 & How much can you do to meet individual language needs of your students using the available textbook? & 4.84 & 2.32 & .67 \\
\hline 12 & How much can you do to familiarize your students with the English culture using the available textbook? & 4.32 & 2.52 & .65 \\
\hline 13 & $\begin{array}{l}\text { How much can you do to use the available textbook to encourage cooperative learning among your students } \\
\text { (pair-work, small group work, etc.)? }\end{array}$ & 5.37 & 2.48 & .55 \\
\hline 14 & $\begin{array}{l}\text { How much can you do to use the available textbook or additional resources to enhance the speaking skill of your } \\
\text { students? }\end{array}$ & 5.08 & 2.53 & .61 \\
\hline 15 & $\begin{array}{l}\text { How much can you do to make the textbook's content relevant to real-life contexts (i.e. to be able to make a } \\
\text { phone call or do shopping, etc.)? }\end{array}$ & 4.91 & 2.58 & .64 \\
\hline
\end{tabular}

\subsection{Validation Study}

Since there was no need to check the factorial structure of teaching self-efficacy scale as done before by TschannenMoran and Woolfolk Hoy (2001), validity study was done just for the SEIIT scale. To conduct validity estimation, three statistical procedures were employed: Bartlett's Test of Sphericity, Kairser-Meyer-Olkin (KMO) measure of sampling adequacy, and principal component factor analysis (PCA). Pallant (2007) emphasizes that prior to running PCA, Bartlett's Test of Sphericity and Kairser-Meyer-Olkin (KMO) measure of sampling adequacy should be estimated in order to verify that the data are suitable for factor analysis. She notes that Bartlett's Test of Sphericity should be significant $(\mathrm{p}<.05)$ and the KMO index should also range from 0 to 1 , with .6 suggested as the minimum value for a good factor analysis. Therefore, the researcher analyzed the SEIIT scale to determine whether the PCA could be run. The data analysis results showed that the it enjoyed a significant level of Bartlett's Test of Sphericity $(\mathrm{p}<.05)$ and KMO value was also acceptable $(\mathrm{KMO}=.89)$. Moreover, the criteria of eigenvalues greater than one and scree test were considered for determining the number of factors to maintain (Pallant, 2007). Also, correlational studies at the item level were done for the devised scale. The correlation matrix indicated that all items were correlated with one another. That is, all of the loadings were higher than .4, which satisfied the condition for conducting PCA (Stevens, 1996, as cited in Lee, 2009; See Appendix B).

The initial factorial analysis of the scale using PCA with varimax rotation of the 15 items revealed that two factors had eigenvalues greater than one and these two factors accounted for $57 \%$ of the variance in the respondents' responses on the scale. However, the researchers examined the pattern of scree test plot and the interpretability of the items loaded under each factor and came to the conclusion that the items suggested for each factor by the PCA were not congruent and did not follow similar themes and topics. Therefore, a one-factor solution was used in this study (See Figure 1 for the Scree Test Plot). The one-factor solution accounted for $43 \%$ of the total variance, "which is somewhat lower than the $53 \%$ average of the factor analysis studies" (Henson \& Roberts, 2001, as cited in Siwatu, 2007, p. 1092).

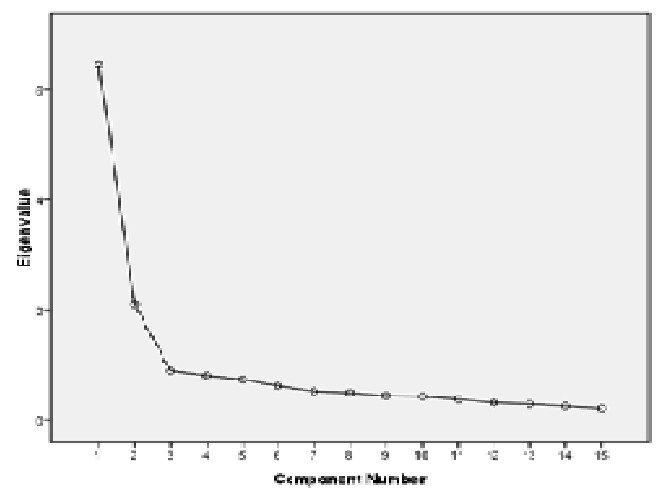

Figure 1. Scree Test Plot of the Eigenvalues for the Principal Components Analysis 
As it was shown in Table 3, the factor loadings ranged from .46 for the ability to "make changes in the lessons to achieve better learning results (for example, changing the sequence of different sections within the same lesson)" to .65 for the ability to "familiarize your students with the English culture using the available textbook".

Also, the reliability of both scales were estimated using Cronbach's alpha that came out to be $.91(a=.91)$ for SEIIT scale and $.87(\alpha=.87)$ for TESES. Furthermore, the reliability of instructional strategies, classroom management and student engagement as sub-scales of teaching self-efficacy scale came out to be $.86, .88$ and .85 respectively - quite acceptable figures.

\subsection{Correlational analysis}

The main hypothesis of the current research was a correlation between general teaching self-efficacy and self-efficacy to influence instructional textbooks. That is, it was hypothesized that those teachers enjoying higher levels of teaching self-efficacy might most probably demonstrate higher levels of self-efficacy to influence instructional textbooks. To investigate this hypothesized correlation, Somers'd statistic was used due to ordinal nature of the scales' items. As it has been suggested, Somers'd statistic is an alternative to Pearson's product-moment correlation coefficient and Spearman's rank-order correlation coefficient for ordinal data (Cyrus \& Nitin, 1995). The relationship between the general teaching self-efficacy and SEIIT came out to be statistically significant (Somers'd statistic $=.45, p<0.01$ ). That is, there is a positive correlation between the two variables. Therefore, the aforementioned hypothesis was confirmed.

Also, Somers'd statistic was re-run in order to investigate the possible relationships of the subcategories of general teaching self-efficacy scale and SEIIT scale. The results confirmed that each of the subcategories, e.g. instructional strategies (Somers'd statistic $=.47, p<0.01$ ), classroom management (Somers'd statistic $=.46, p<0.01$ ) and student engagement (Somers'd statistic $=.48, p<0.01$ ), had moderate correlations with SEIIT.

\section{Discussion \& Conclusion}

As discussed above, this study at first aimed to develop a measure of self-efficacy to influence instructional textbooks, in order to examine how much teachers perceive themselves as capable of bringing about better learning outcomes by modifying the textbooks they have available. The task was then to examine the possible relationship of this construct with general teaching self-efficacy, the significance of which seems to be quite important and relevant for the realm of self-efficacy research. The upcoming section is devoted to the concluding remarks of the research findings and the implications of this research for future studies.

Examining the pattern of responses given to the teaching self-efficacy scale showed that high school English language teachers enjoyed a high level of teaching self-efficacy. The evidence for this claim is that more than $63 \%$ of teachers selected 9 or 8 for their answers. Also the item-specific means showed that the participants perceived themselves to be more capable in controlling disruptive behaviors in their English classes and less capable in assisting parents to help their children learn English. A possible justification for these results is that Iranian classroom context is totally teacherfronted, and as the literature tells us, in such classes the teacher is regarded as the most powerful authority in the classroom and is responsible for bringing about learning in her students (Allen, 2004; Huba \& Freed, 2000; Weimer, 2002). Therefore, it is not surprising that Iranian high school language teachers are better at avoiding any disruptive behavior than in assisting parents to help their children, because for many years they have been accustomed to seeing students as passive receivers of information. An alternative justification for why the teachers rated themselves as incapable of involving parents in the process of language learning can be accounted for by the fact the fact that most Iranian parents do not have an appropriate grasp of the English language. Therefore, language teachers cannot rely much on parents to be capable of supporting the English language learning of their children.

Regarding the SEIIT scale, the teachers rated highest the item about increasing the grammaticality of their students using a variety of techniques such as repeating the grammatical points presented in one lesson in other lessons. The justification for this high rating is that the available high school textbooks are grammar-based and teachers put high value on the grammaticality of student's language performance. Also, the item that received lowest rating was using the available textbook to familiarize students with the culture of English-speaking countries. A quick analysis of the currently employed English textbooks shows that the writers have done their best to minimize the traces of Western culture in their books ("Iranian textbooks content and contexts", 2007). The most interesting point was that even those teachers that reported a high level of teaching self-efficacy were unable to compensate for this problem.

The question that now comes to mind is how the efficacious teachers approached those areas of the English textbooks to which due attention has not been paid, such as developing listening and speaking skills. The item-specific means showed that teachers with high levels of self-efficacy still had problems in this area. That is, they were not able to provide much help to their students in developing their speaking and listening skills. The same story was true for the task of making the current textbooks relevant to the real-world language needs of students. A possible justification for these results was - although it has been suggested that teachers with high levels of teaching self-efficacy can surmount the teaching barriers (Bruce et al., 2010) - it seems that the type of teaching barriers with which they are faced should be taken into account. That is, according to the literature, people who are equipped with strong sense of self-efficacy try to surmount failures or obstacles by increasing their effort (Bruce et al., 2010; Hoy \& Spero, 2005). But the current research showed that even teachers with robust sense of self-efficacy could not surmount the deeply rooted problems found in the prescribed textbooks.

The results of this study had empirical implications for teacher education programs and theoretical implications regarding teacher self-efficacy. First, although teachers may perceive themselves capable (i.e. efficacious) in 
overcoming the foreseeable teaching obstacles, when it comes to such severe problems as poorly-developed English language textbooks, they may not feel sufficiently efficacious. Therefore, the nature of the obstacles can influence the teachers' sense of self-efficacy. Second, the teacher education programs can be planned in such a way that teachers be equipped with tactics on how to deal with such deeply rooted problems such as those we explained in high school English textbooks. That is, teachers can be advised as to how to devote a portion of class time to developing those skills that have not received due attention.

\section{Acknowledgments}

There are many who deserve our most sincere gratitude for their role in transforming this research into a presentable product, foremost among them being the Iranian high school English language teachers who willingly participated in our study. Also, we are ever so grateful to those who took the responsibility of translating the scales from Persian to English and vice versa. Last and not the least, we appreciate the comments and the insightful feedback we received on our early draft from Mrs. Hamideh Jamshidiha.

\section{References}

Allen, M., J. (2004). Assessing academic programs in higher education. Bolton: Anker Publishing Company, INC.

Allinder, R. M. (1995). An examination of the relationship between teacher efficacy and curriculum-based measurement and student achievement. Remedial \& Special Education, 16(4), 247-254.

Anderson, R., Greene, M., \& Loewen, P. (1988). Relationships among teachers' and students' thinking skills, sense of efficacy, and student achievement. Alberta Journal of Educational Research, 34(2), 148-165.

Armor, D., Conroy-Osegnera, P., Cox, M., \& King, N. (1976). Analysis of the school preferred reading programs in selected Los Angels minority schools. Report No. R-2007 LAUSD. Santa Monica, CA: RAND Corporation (ERIC Document Reproduction Service No. ED 130243).

Ashton, P, T., \& Webb, R.B. (1986). Making a difference: Teachers sense of efficacy and student achievement. New York: Longman.

Bandura, A. (1977). Self-efficacy: Toward a unifying theory of behavioral change. Psychological Review, 84(2), 191215.

Bandura, A. (1986). Social foundations of thought and action: A social cognitive theory. Englewood Cliffs, NJ: Prentice-Hall.

Bandura, A. (1989). Social cognitive theory. In R. Vasta (Ed.), Annals of child development. Six theories of child development (pp. 1-60), Greenwich, CT: JAI Press.

Bandura, A. (1993). Perceived self-efficacy in cognitive development and functioning. Educational Psychologist, 28(2), 117-148.

Bandura, A. (1997). Self-efficacy: the exercise of control. New York: W.H. Freeman and Company.

Bandura, A. (2001). Guide for constructing self-efficacy scales (Monograph). Stanford, CA: Stanford University.

Bandura, A. (2006a). Adolescent development from an agentic perspective. In F. Pajares \& T. Urdan (Eds.), Selfefficacy beliefs of adolescents, (pp. 1-43). Greenwich, CT: Information Age Publishing.

Bandura, A. (2006b). Guide for constructing self-efficacy scales. In F. Pajares \& T. Urdan (Eds.), Self-efficacy beliefs of adolescents (pp. 307-337). Greenwich, CT: Information Age.

Borg, S. (2003). Teacher cognition in language teaching: A review of research on what language teachers think, know, believe, and do. Language Teaching, 36(2), 81-109.

Brownell, M. T., \& Pajares, F. (1999). Teacher efficacy and perceived success in mainstreaming students with learning and behavior problems. Teacher Education and Special Education, 22(3), 154-164.

Bruce, C. D., Esmonde, I., Ross, J., Dookie, L., \& Beatty, R. (2010).The effects of sustained classroom-embedded teacher professional learning on teacher efficacy and related student achievement. Teaching and Teacher Education, 26(8), 1598-1608.

Byrd, P. (2001). Textbooks: Evaluation for selection and analysis for implementation. In M. Celce-Murcia (Ed.), Teaching English as a second or foreign language ( ${ }^{\text {rd }}$ edition, pp. 415-427). New York: Heinle \& Heinle.

Cattell, R. B. (1966). The scree test for the number of factors. Multivariate Behavioral Research, 1(2), $245-276$.

Cunningsworth, A. (1984). Evaluating and selecting EFL teaching materials. London: Heinemann Educational Books.

Cyrus, R.M. \& Nitin, R.P. (2011). IBM SPSS exact tests. New York: IBM.

Dahmardeh, M. (2009). Communicative textbooks: English language textbooks in Iranian secondary school. Linguistik online, 40(4), 45-61.

Dahmardeh, M. (2011). Authentic or not? A case study on the role of authenticity in English language teaching in Iran. Journal of English Language Teaching and Learning, 7, 67-87. 
Dembo, M. H., \& Gibson, S. (1985). Teachers' sense of efficacy: An important factor in school improvement. The Elementary School Journal, 86(2), 173-184.

Dornyei, Z. (2003). Questionnaires in second language research: Construction, administration, and processing. London: LEA.

Eren, A. (2009). Examining the teacher efficacy and achievement goals as predictors of Turkish student teachers' conceptions about teaching and learning. Australian Journal of Teacher Education, 34(1), 69-87.

Eslami, Z.R. \& Fatahi, A. (2008). Teachers' sense of self-efficacy, English proficiency, and instructional strategies: A study of non-native EFL teachers in Iran. TESL-EJ, 11 (4), 1-19.

Fives, H. (2003). What is teacher efficacy and how does it relate to teachers' knowledge?: A theoretical review. Paper presented at the American Educational Research Association Annual Conference. Retrieved from msuweb.montclair.edu/ fivesh/research_files/fives_aera_2003.pdf

Garinger, D. (2002). Textbook selection for the ESL classroom. Retrieved from www.cal.org/resources/digest/digest_pdfs/0210garinger.pdf.

Ghorbani, M.R. (2009). ELT in Iranian high schools in Iran, Malaysia and Japan: Reflections on how tests influence use of prescribed textbooks. Reflections on English Language Teaching, 8(2), 131-139.

Gibson, S., \& Dembo, M. (1984). Teacher efficacy: A construct validation. Journal of Educational Psychology, 76(4), 569-589.

Goddard, R. D., Hoy, W. K., \& Woolfolk Hoy, A. (2000). Collective teacher efficacy: Its meaning, measure, and impact on student achievement. American Educational Research Journal, 37(2), 479-507.

Guskey, T.R. (1981). Measurement of responsibility teachers assume for academic successes and failures in the classroom. Journal of Teacher Education, 32(3), 44-51.

Guskey, T. R. (1987). Context variables that affect measures of teacher efficacy. Journal of Educational Research, 81(1), 41-47.

Guskey, T. R. (1988). Teacher efficacy, self-concept, and attitudes toward the implementation of instructional innovation. Teaching and Teacher Education, 4(1), 63-69.

Haverback, H. R., \& Parault, S.J. (2011). High efficacy and the preservice reading teacher: A comparative study. Teaching and Teacher Education, 27(4), 1-9.

Hoy, A. W., \& Spero, R. B. (2005). Changes in teacher efficacy during the early years of teaching: A comparison of four measures. Teaching and Teacher Education, 21(4), 343-356.

Hoy, W. K., \& Woolfolk, A. E. (1990). Organizational socialization of student teachers. American Educational Research Journal, 27(2), 279-300.

Howell, C. (2005). Democratic education and social learning theory. Philosophy of Education Yearbook, 161-70.

Huba, M. E. \& Freed, J. E. (2000). Learner-centered assessment on college campuses: Shifting the focus from teaching to learning. Boston, MA: Allyn \& Bacon.

Hutchinson, T., \& Torres, E. (1994). The Textbook as Agent of Change. ELT Journal, 48(4), 315-328.

Iranian textbooks content and context. (2007, December 31). Science Applications International Corporation. Retrieved from www.fas.org/irp/dni/osc/irantext.pdf

Kaiser, H. F. (1960). The application of electronic computers to factor analysis. Educational and Psychological Measurement, 20(1), 141-151.

Karl, F., \& Wheatley, K. F. (2005). The case for reconceptualizing teacher efficacy research. Teaching and Teacher Education, 21(7), 747-766.

Knoblauch, D., \& Woolfolk Hoy, A. (2008). "Maybe I can teach those kids. 'The influence of contextual factors on student teachers' efficacy beliefs. Teaching and Teacher Education, 24(1), 166-179.

Lee, J.A. (2009). Teachers' sense of efficacy in teaching English, perceived English language proficiency, and attitudes toward the English language: A case of Korean public elementary school teachers. A doctoral dissertation. Retrieved from https://etd.ohiolink.edu/ap:10:0::NO:10:P10_ACCESSION_NUM:osu1233648070.

Noora, A. (2008). Iranian undergraduates non-English majors' language learning preferences. GEMA Online Journal of Language Studies, 8(2), 33-44.

Pajares, F. (1992). Teachers' beliefs and educational research: Cleaning up a messy construct. Review of Educational Research, 62(3), 307-332.

Pajares, F. (1996). Self-efficacy beliefs in academic settings. Review of educational research, 66(4), 543-578.

Pajares, F. \& Schunk, D. H. (2002). Self and self-belief in psychology and education: An historical perspective. In J. Aronson (Ed.), Improving Academic Achievement (pp. 3-15). New York: Academic Press.

Pallant, J. (2007). SPSS: Survival Manual. New York: Open University Press. 
Podell, D. M., \& Soodak, L. C. (1993). Teacher efficacy and bias in special education referral. Journal of Educational Research, 86(4), 247-253.

Razmjoo, S.A. (2007). High schools or private institutes textbooks? Which fulfill communicative language teaching principles in the Iranian context? Asian EFL Journal, 9(4), 126-140.

Ross, J. A. (1992). Teacher efficacy and the effects of coaching on student achievement. Canadian journal of education, 17(1), 51-65.

Ross, J. A. (1998). Antecedents and consequences of teacher efficacy. In J. Brophy (Ed.), Expectations in the classroom (pp. 49-74). Greenwich, CT: JAI Press.

Rotter, J. B. (1954). Social learning and clinical psychology. Englewood Cliffs, NJ: Prentice Hall.

Sheldon, L. (1988). Evaluating ELT Textbooks and Materials. ELT Journal, 42(4), 237-246.

Siwatu, K.O. (2007). Preservice teachers' culturally responsive teaching self-efficacy and outcome expectancy beliefs. Teaching and teacher education, 23(7), 1086-1101.

Skaalvik, E., \& Skaalvik, S. (2007). Dimensions of teacher self-efficacy and relations with strain factors, perceived collective teacher efficacy, and teacher burnout. Journal of Educational Psychology, 99(3), 611-625.

Soodak, L. C., \& Podell, D. M. (1996). Teacher efficacy: Toward the understanding of a multi-faceted construct. Teaching \& teacher education, 12(4), 401-411.

Soori, A., Kafipour, R., \& Soury, M. (2011). EFL textbook evaluation and graphic representation. European Journal of Social Sciences, 26(3), 481-493.

Tournaki, N., \& Podell, D. M. (2005). The impact of student characteristics and teacher efficacy on teachers' predictions of student success. Teaching and Teacher Education, 21 (3), 299-314.

Tschannen-Moran, M., Woolfolk Hoy, A. \& Hoy, W. K. (1998). Teacher efficacy: Its meaning and measure. Review of Educational Research, 68(2), 202 - 248.

Tschannen-Moran, M., \& Woolfolk Hoy, A. (2001). Teacher efficacy: Capturing an elusive construct. Teaching and Teacher Education, 17(7), 783-805.

Weimer, M. (2002). Learner-centered teaching: Five key changes to practice. San Francisco: Jossey-Bass.

Weiner, B. (1979). A theory of motivation for some classroom experiences. Journal of Educational Psychology, 71(1), 3-25.

Wheatley, K. F. (2005). The case for reconceptualizing teacher efficacy research. Teaching and Teacher Education, 21(7), 747-766.

Wolters, C. A., \& Daugherty, S. G. (2007). Goal structures and teachers' sense of efficacy: Their relation and association to teaching experience and academic level. Journal of Educational Psychology, 99(1), 181-193.

Woolfolk, A. E., \& Hoy, W. K. (1990). Prospective teachers' sense of efficacy and beliefs about control. Journal of Educational Psychology, 82(1), 81-91.

Woolfolk Hoy, A., \& Spero, R. B. (2005). Changes in teacher efficacy during the early years of teaching: A comparison of four measures. Teaching and Teacher Education, 21(4), 343-356.

Yogh, M.S. (2008). Teachers' Perceptions of Ability: Measuring Teacher Efficacy for Instructing the ESOL Student. Retrieved from https://kb.osu.edu/dspace/bitstream/1811/.../Yough-Hayes_Paper.pdf. 


\section{Appendix A}

\section{Self-Efficacy to Influence Instructional Textbooks (SEIIT) Scale}

Instruction: This questionnaire contains a number of questions regarding how much you feel competent to derive the best outcome from the current high school English textbook that you are using. Please note that this is not a test. Therefore, there is no right or wrong answer. Please be assured that all of the information obtained from this scale will be kept completely confidential.

\begin{tabular}{|c|c|c|c|c|c|c|c|c|c|c|}
\hline No. & Items & 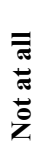 & 2 & $\begin{array}{l}\frac{0}{E} \\
\frac{D}{D} \\
\frac{D}{2}\end{array}$ & 4 & 异 & 6 & 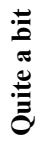 & 8 & 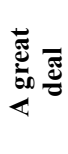 \\
\hline 1 & $\begin{array}{l}\text { How much can you do to make changes in the book's lessons to } \\
\text { achieve better learning results (for example, changing the sequence } \\
\text { of different sections within the same lesson)? }\end{array}$ & 1 & 2 & 3 & 4 & 5 & 6 & 7 & 8 & 9 \\
\hline 2 & $\begin{array}{l}\text { How much can you do to supplement the materials presented in the } \\
\text { textbook with other resources (short story, newspaper, etc.)? }\end{array}$ & 1 & 2 & 3 & 4 & 5 & 6 & 7 & 8 & 9 \\
\hline 3 & $\begin{array}{l}\text { How much can you do to use the available textbook or additional } \\
\text { resources to enhance the writing skill of your students? }\end{array}$ & 1 & 2 & 3 & 4 & 5 & 6 & 7 & 8 & 9 \\
\hline 4 & $\begin{array}{l}\text { How much can you do to make the textbook more interesting and } \\
\text { attractive for your students at this age? }\end{array}$ & 1 & 2 & 3 & 4 & 5 & 6 & 7 & 8 & 9 \\
\hline 5 & $\begin{array}{l}\text { How much can you do to employ a diversity of tasks and exercises } \\
\text { to teach the textbook in order to meet the different learning styles } \\
\text { and interests of your students? }\end{array}$ & 1 & 2 & 3 & 4 & 5 & 6 & 7 & 8 & 9 \\
\hline 6 & $\begin{array}{l}\text { How much can you do to employ a variety of reading techniques to } \\
\text { make your students better readers (based on the potentials of the } \\
\text { current textbook)? }\end{array}$ & 1 & 2 & 3 & 4 & 5 & 6 & 7 & 8 & 9 \\
\hline 7 & $\begin{array}{l}\text { How much can you do to use the textbook to increase the } \\
\text { grammaticality of your students' language (i.e. repeating the } \\
\text { grammatical points presented in one lesson in other lessons so that } \\
\text { to stabilize those points)? }\end{array}$ & 1 & 2 & 3 & 4 & 5 & 6 & 7 & 8 & 9 \\
\hline 8 & $\begin{array}{l}\text { How much can you do to improve your students' pronunciation } \\
\text { using the textbook pronunciation exercises? }\end{array}$ & 1 & 2 & 3 & 4 & 5 & 6 & 7 & 8 & 9 \\
\hline 9 & $\begin{array}{l}\text { How much can you do to use the available textbook or additional } \\
\text { resources to enhance the listening skill of your students? }\end{array}$ & 1 & 2 & 3 & 4 & 5 & 6 & 7 & 8 & 9 \\
\hline 10 & $\begin{array}{l}\text { How much can you do to use the textbook to encourage students to } \\
\text { use additional resources such as Internet for further learning? }\end{array}$ & 1 & 2 & 3 & 4 & 5 & 6 & 7 & 8 & 9 \\
\hline 11 & $\begin{array}{l}\text { How much can you do to meet individual language needs of your } \\
\text { students using the available textbook? }\end{array}$ & 1 & 2 & 3 & 4 & 5 & 6 & 7 & 8 & 9 \\
\hline 12 & $\begin{array}{l}\text { How much can you do to familiarize your students with the English } \\
\text { culture using the available textbook? }\end{array}$ & 1 & 2 & 3 & 4 & 5 & 6 & 7 & 8 & 9 \\
\hline 13 & $\begin{array}{l}\text { How much can you do to use the available textbook to encourage } \\
\text { cooperative learning among your students (pair-work, small group } \\
\text { work, etc.)? }\end{array}$ & 1 & 2 & 3 & 4 & 5 & 6 & 7 & 8 & 9 \\
\hline 14 & $\begin{array}{l}\text { How much can you do to use the available textbook or additional } \\
\text { resources to enhance the speaking skill of your students? }\end{array}$ & 1 & 2 & 3 & 4 & 5 & 6 & 7 & 8 & 9 \\
\hline 15 & $\begin{array}{l}\text { How much can you do to make the textbook's content relevant to } \\
\text { real-life contexts (i.e. to be able to make a phone call or do } \\
\text { shopping, etc.)? }\end{array}$ & 1 & 2 & 3 & 4 & 5 & 6 & 7 & 8 & 9 \\
\hline
\end{tabular}


Appendix B

Correlation Matrix for the Items of Self-Efficacy to Influence Instructional Textbooks (SEIIT) Scale

\begin{tabular}{|c|c|c|c|c|c|c|c|c|c|c|c|c|c|c|c|}
\hline & 1 & 2 & 3 & 4 & 5 & 6 & 7 & 8 & 9 & 10 & 11 & 12 & 13 & 14 & 15 \\
\hline 1 & 1.00 & & & & & & & & & & & & & & \\
\hline 2 & .46 & 1.00 & & & & & & & & & & & & & \\
\hline 3 & .43 & .60 & 1.00 & & & & & & & & & & & & \\
\hline 4 & .41 & .50 & .45 & 1.00 & & & & & & & & & & & \\
\hline 5 & .4 & .46 & .42 & .44 & 1.00 & & & & & & & & & & \\
\hline 6 & .42 & .51 & .43 & .52 & .45 & 1.00 & & & & & & & & & \\
\hline 7 & .55 & .44 & .46 & .51 & .51 & .45 & 1.00 & & & & & & & & \\
\hline 8 & .51 & .43 & .5 & .45 & .4 & .51 & .46 & 1.00 & & & & & & & \\
\hline 9 & .43 & .49 & .44 & .49 & .41 & .48 & .47 & .46 & 1.00 & & & & & & \\
\hline 10 & .63 & .5 & .55 & .45 & .65 & .51 & .61 & .59 & .52 & 1.00 & & & & & \\
\hline 11 & .48 & .4 & .49 & .5 & .49 & .45 & .51 & .47 & .44 & .52 & 1.00 & & & & \\
\hline 12 & .52 & .42 & .51 & .62 & .56 & .57 & .55 & .54 & .43 & .53 & .47 & 1.00 & & & \\
\hline 13 & .52 & .51 & .49 & .48 & .47 & .53 & .5 & .46 & .45 & .53 & .47 & .55 & 1.00 & & \\
\hline 14 & .4 & .66 & .55 & .43 & .56 & .65 & .41 & .42 & .44 & .43 & .43 & .51 & .44 & 1.00 & \\
\hline 15 & .45 & .47 & .4 & .54 & .49 & .55 & .54 & .53 & .46 & .41 & .49 & .49 & .47 & .46 & 1.00 \\
\hline
\end{tabular}

